\title{
FLORA MALESIANA PRECURSOR FOR THE TREATMENT OF MORACEAE 4: FICUS SUBGENUS SYNOECIA
}

\author{
C.C. BERG \\ The Norwegian Arboretum/Botanical Institute, University of Bergen, \\ N-5259 Hjellestad, Norway; Nationaal Herbarium Nederland, Universiteit Leiden branch, \\ P.O. Box 9514, 2300 RA Leiden, The Netherlands
}

SUMMARY

The sections and subsections of Ficus subg. Synoecia are described and their Malesian species listed and keyed out. Six new species are described or established in the subgenus: F. cavernicola, F. colobocarpa, $F$. jacobsii, $F$. jimiensis, $F$. sohotonensis, and $F$. submontana. The combination $F$. disticha Blume subsp. calodictya (Summerh.) C.C. Berg is made and the lectotypes for F. alococarpa Diels and F. simiae H.J.P. Winkl. are designated.

Key words: Moraceae, Ficus subg. Synoecia, Malesia.

\section{INTRODUCTION}

Ficus subg. Synoecia is described and discussed in the proposed subdivision of the genus (Berg, 2003). The present contribution deals with the subdivision of this subgenus, lists the species currently recognised for the region and new species and subspecies discovered, and a key to the Malesian species. The formal subdivision is limited to sections in which a number of informal groups of presumably related species are distinguished; the ranks of series and subseries are not applied. Most of the varieties recognised by Corner $(1960,1965)$ are not maintained, some are recognised as species, some others transferred to other species (as indicated in the list of species).

The identity of Ficus gamostyla Kochummen and F. ilias-paiei Kochummen (1998) could not yet be verified as the type material was not made available.

\section{SUBDIVISIONS AND SPECIES}

Ficus subg. Synoecia sect. Kissosycea Miq. (1848) 452

Lamina of the acrophylls often \pm asymmetric, the lower surface foveolate or (brown) tessellate (when dry). Figs often cauliflorous, the receptacle often large, the basal bracts persistent. Staminate and neuter flowers mostly scattered among the pistillate ones, sometimes near the ostiole, the pedicels often long. Stamens 1, sometimes 2, the anthers elliptic to oblong in outline, not mucronate. Tepals of the pistillate flowers lanceolate to linear to almost subulate, mostly red. Ovaries of short-styled flowers (dark) red-brown. 
Distribution - This section comprises 27 (or 28?) species and ranges from Sri Lanka to Australia and the Solomon Islands; only two species (F. diversiformis Miq. and F. hederacea Roxb.) are confined to the Asian mainland, the others occur in the Malesian region.

Delimitation - The section comprises subg. Ficus sect. Kalosyce (Miq.) Corner ser. Apiocarpeae Corner (1960) 22 and ser. Punctatae Corner (1960) 22 with subser. Punctatae and subser. Ruginerviae Corner (1960) 22, and sect. Rhizocladus with ser. Distichae Corner (1960) 5 and ser. Distichoideae Corner (1960) 5.

Subdivision - The section is rather homogeneous, but allows recognition of two groups, mainly based on differences of the areoles: foveolate versus tessellate.

1) F.punctata-group (ser. Punctatae), comprising the species numbered: 4, 5, 6, 7, 12 , $13,16,17,18,19,20,23$, and 24.

2) F.apiocarpa-group (ser. Apiocarpeae, ser. Distichae, and ser. Distichoideae), comprising the species numbered: 1, 2, 3, 8, 9, 10, 11, 14, 15, 21, 22, and 25 .

Malesian species currently recognized in sect. Kissosycea: 1) F. allutacea Blume; 2) F. apiocarpa (Miq.) Miq.; 3) F. barba-jovis Corner; 4) F. carrii Corner; 5) F. cataupi Elmer; 6) F. cavernicola C.C. Berg (see below); 7) F. densechini Corner; 8) F. detonsa Corner; 9) F. diandra Corner; 10) F. disticha Blume, with a) subsp. disticha and b) subsp. calodictya (Summerh.) C.C. Berg (see below; incl. F. agapetoides Diels, F. agapetoides var. solomonensis Corner, F. calodictya var. gamophylla Corner, F. meiocarpa Diels, and F. phatnophylla var. meiocarpa (Diels) Corner); 11) F. distichoidea Diels; 12) F. grandiflora Corner; 13) F. gymnorygma Summerh.; 14) F. peninsula Elmer; 15) F. phatnophylla Diels; 16) F. punctata Thunb. (incl. F. aurantiacea Griff. and F. simiae H.J.P. Winkl.); 17) F. ruginervia Corner; 18) F. sarawakensis Corner; 19) F. scratchleyana King; 20) F. singalana King; 21) F. sohotonensis C.C. Berg (see below); 22) F. submontana C.C. Berg (see below); 23) F. trachycoma Miq.; 24) F. tulipifera Corner; 25) F. warburgii Elmer. - For other synonyms and (included) varieties see Corner's check-list (1965: 57-58 and 60-62).

Note - The type of F. simiae H.J.P. Winkl. (1913) 362, Winkler 2515 from SE Borneo, Hayup, 16 June 1908, is a mixed collection, consisting of some pieces of a fig belonging to F p punctata and a lamina probably belonging to Poikilospermun cordifolium (Barg.-Petr.) Merr. (Cecropiaceae), the former element is here designated as lectotype.

Ficus subg. Synoecia sect. Rhizocladus Endl. (1848) 34

Lamina of the acrophylls (usually) symmetric, the lower surface mostly not foveolate (or if tessellate then only faintly so). Figs mostly axillary, just below the leaves, or (clustered) on short spurs on the older wood (ramiflorous), the receptacle often small, the basal bracts persistent or caducous. Staminate and neuter flowers scattered among the pistillate ones or near the ostiole, usually (sub) sessile. Stamens 2, sometimes 1 (or 3 ), the anthers lanceolate to oblong in outline, usually mucronate. Tepals of the pistillate flowers subovate to elliptic to oblong to subobovate, red. Ovaries of short-styled flower red(dish).

Subdivision - Within this section, four subsections can be distinguished. 
Ficus subg. Synoecia sect. Rhizocladus subsect. Plagiostigma (Miq.) C.C. Berg, stat. nov.

Based on: Ficus sect. Plagiostigma Siebold \& Zucc. ex Miq. (1848) 436. - Type: Ficus pumila L.

Indumentum consisting of \pm soft straight or crinkled hairs without swollen bases. Leafy twigs eglandular. Leaves differentiated into bathyphylls and acrophylls, spirally alternate (or acrophylls in lax spirals); lamina of acrophyll symmetric (or slightly asymmetric); petiole short. Figs axillary; internal hairs rather sparse and whitish to abundant and brownish. Staminate flowers near the ostiole. Tepals red, glabrous or hairy at the apex. Fruits compressed and keeled or hardly compressed and not keeled.

Distribution - This subsection comprises eight (or ten?) species and ranges from north-eastern India through Myanmar, Thailand, Indochina and China to Korea, Japan, and Taiwan; only F. pubigera extends to the Malay Peninsula.

In the Malesian region represented by: 26) F. pubigera (Wall. ex Miq.) Miq.; 27) F. pumila L. (in cultivation).

Ficus subg. Synoecia sect. Rhizocladus subsect. Pogonotrophe (Miq.) C.C. Berg, stat. nov.

Based on: Pogonotrophe Miq. (1847) 525. - Ficus subg. Pogonotrophe (Miq.) Miq. (1867) 293. - Ficus subg. Ficus sect. Rhizocladus ser. Plagiostigmaticae subser. Pogonotropheae Corner (1960) 4. - Type: Ficus laevis Blume.

Indumentum consisting of \pm soft straight or crinkled hairs without swollen bases. Leafy twigs with a pair of subnodal waxy glands below the petioles. Leaves not clearly differentiated into bathyphylls and acrophylls, spirally alternate; lamina symmetric; petiole long. Figs axillary (or cauliflorous); internal hairs abundant, stiff, long (at anthesis as long as the pistillate flowers, and separating the stigmas), brownish. Staminate flowers near the ostiole. Tepals red, glabrous. Stamens 2 (or 3), filaments free, anthers oblong in outline. Fruits hardly compressed and not keeled.

Distribution - With a single species, ranging from Sri Lanka to S China, Java, and Borneo.

The only species of subsect. Pogonotrophe: 28) F. laevis Blume.

Ficus subg. Synoecia sect. Rhizocladus subsect. Punctulifoliae Sata (1944) 329. - Lectotype (Corner, 1960: 4): Ficus villosa Blume

Indumentum usually partly or largely consisting of stiff (to setose) hairs with \pm swollen bases. Leafy twigs eglandular. Lamina symmetric, mostly \pm densely hairy beneath, areoles not marked, or if marked, then foveolate with small stomatal pits or minutely bullate; petiole mostly short. Figs axillary and mostly also below the leaves (ramiflorous, or possibly sometimes cauliflorous), on short spurs already developing in the leaf axils, on the spurs the figs often clustered, already in the leaf axils or mainly below the leaves; receptacle small to rather large, often stipitate, basal bracts often caducous, ostiole often sunken. Staminate and neuter flowers near the ostiole. Stamens 2 or 1, the filaments often basally connate. Fruits \pm compressed, \pm distinctly keeled. 
Distribution - This subsection comprises 26 species, all occurring in the Malesian region, some with extensions to the Asian mainland, others with extensions to Australia and/or the Solomon Islands.

Delimitation - The subsection comprises subg. Ficus sect. Rhizocladus ser. Ramentaceae Corner (1960) 4.

Subdivision - Within this subsection two major sets of species can be recognized:

1) $F$. villosa-group with two subgroups:

a) F. villosa-subgroup (subser. Ramentaceae Corner (1960) 4), comprising the species numbered: 32, 45, 46, 47, 48, 50, 51, and 53.

b) F. excavata-subgroup (subser. Araneosae and Excavatae Corner (1960) 4) comprising the species numbered: 30,35, 41, and 52 .

2) F. baeuerlenii-group (subser. Balanotae and Irritantes Corner (1960) 4), comprising the species numbered: $29,31,33,34,36,37,38,39,40,42,43,44$, and 49.

Malesian species currently recognised in subsect. Punctilifoliae: 29) F. ampulliformis Corner; 30) F. araneosa King; 31) F. baeuerlenii King (incl. F. balanota Diels); 32) F. camptandra Diels; 33) F. colobocarpa (Corner) C.C. Berg (see below); 34) F. devestiens Corner; 35) F. excavata King; 36) F. floccifera Diels; 37) F. fuscata Summerh.; 38) F. hypobrunnea Corner; 39) F. insculpta Summerh. (incl. F. ceanothifolia Corner, F. convexa Corner); 40) F. jacobsii C.C. Berg (see below); 41) F. lanata Blume; 42) F. odoardii King (incl. F. irritans Summerh. and F. sphaerocarpa Corner); 43) F. ovatacuta Corner (incl. F. pantoniana var. rhytidophloea Corner); 44) F. oxymitroides Corner; 45) F. pantoniana King (excl. var. colobocarpa Corner, see above); 46) F. pendens Corner; 47) F. recurva Blume, with a) var. recurva; b) var. elegantior Corner; c) var. pedicellata Corner, incl. F. uncinulata Corner; d) var. ribesioides (Miq.) King; e) var. urnigera (Miq.) King; 48) F. sabahana Kochummen (1998) 211; 49) F. sageretina Diels (incl. F. amblisyce Corner); 50) F. sagittata J. König ex Vahl; 51) F. spiralis Corner; 52) F. supperforata Corner; 53) F. villosa Blume (incl. F. grossivenis Corner). - For other synonyms and (included) varieties see Corner's check-list (1965: 53-57).

Ficus subg. Synoecia sect. Rhizocladus subsect. Trichocarpeae (Corner) C.C. Berg, stat. nov.

Based on: Ficus subg. Ficus sect. Rhizocladus ser. Trichocarpeae Corner (1960) 5. - Type: Ficus trichocarpa Blume.

Indumentum consisting of straight hairs without (distinctly) swollen bases; the pluricellular trichomes oblongoid-capitate. Leafy twigs eglandular. Lamina often ovate to (sub)cordiform. Stipules short and the terminal buds rather thick; petiole short. Figs axillary, mostly in pairs, pedunculate, occasionally sessile; basal bracts persistent, occasionally caducous, often spreading to \pm reflexed; receptacle (sub)globose, non-stipitate (or substipitate); ostiole often \pm prominent. Tepals usually red, glabrous. Staminate and neuter flowers scattered among the pistillate ones; filaments free. Ovaries of the short-styled flower red-brown. Fruits \pm compressed, not keeled.

Distribution - This subsection comprises 10 species and ranges from the Asian mainland to the Solomon Islands. Ficus nasuta Summerh. is endemic to the Solomon 
Islands, the others are Malesian. Ficus trichocarpa extends to the Asian mainland; the closely related F. bakeri and F. perfulva are endemics of the Philippines; the other Malesian species are confined to eastern New Guinea and New Britain.

Notes -1 . This subsection is the least specialized one, as with regard to the features of indumentum and figs. It shows resemblances with subg. Ficus, in particular sect. Eriosycea.

2. Distinctly pedunculate figs with well-developed basal bracts are characteristic for subsect. Trichocarpeae, but a few species differ in having (sub)sessile figs (F. hypophaea) or caducous basal bracts (F. bakeri).

3. The lower surface of the lamina tends to become subtessellate in some species, as in F. trichocarpa, but in contrast to the truly tessellate laminas of sect. Kissosycea, the veinlets are hairy.

Malesian species currently recognised in subsect. Trichocarpeae: 54) F. bakeri Elmer; 55) F. cinnamomea Corner (incl. F. hypophaeola Corner); 56) F. hypophaea Schltr.; 57) F. jimiensis C.C. Berg (see below; incl. F. nasuta Summerh. var. glabrata Corner); 58) F. perfulva Elmer ex Merr.; 59) F. phaeobullata Corner; 60) F. pleiadenia Diels (incl. F. alococarpa Diels and F. semilanata Corner); 61) F. supfiana Schltr.; 62) F. trichocarpa Blume. - For other synonyms and (included) varieties see Corner's check-list (1965: $59-60)$.

Note - Ficus alococarpa Diels is based on a mixed collection, Ledermann 13078 (holo B), Papua New Guinea, 'Felsspitze', 23 Aug. 1913, consisting of a leafy twig belonging to $F$. odoardii King, and leafless twigs with figs, the latter element is selected as the lectotype and included in F. pleiadenia.

\section{NEW SPECIES AND COMBINATIONS}

\section{Ficus cavernicola C.C. Berg, spec.nov. - Fig. 1}

Fico cataupi similis, venis lateralibus numerosioribus supra impressis, syconii receptaculis depresse globosis distincta. - Typus: Chew \& Corner RSNB 4766 (holo SAN; L), Malaysia, Sabah, Mt Kinabalu, Mesilau Cave, c. 2000 m, 30 March 1964.

Root-climber. Branchlets drying brown. Leafy twigs 2-4 mm thick, solid, (rather) densely brown hirtellous to pilose. Leaves distichously alternate; lamina elliptic, 5-6 by $3-3.5 \mathrm{~cm}$, almost symmetric, coriaceous, apex subacute to obtuse, base \pm inequilateral to almost equilateral, if inequilateral, then the broad side often slightly decurrent and (sub)auriculate, the narrow side rounded to obtuse, if equilateral, then rounded to cordulate, margin entire, revolute; upper surface glabrous, lower surface sparsely pilose to puberulous on the main veins, (glabrescent), minutely puberulous on the rims of the areoles; cystoliths only beneath; midrib slightly prominent to flat (but in a depression) and lateral veins \pm impressed above, lateral veins $8-10$ pairs, the basal pair at the broad side of the lamina up to c. 1/10-1/6 the length of the lamina, unbranched, tertiary venation reticulate, the smaller veins slightly prominent to flat beneath, the areoles foveolate; waxy glands absent; petiole $0.5-1 \mathrm{~cm}$ long, sparsely puberulous, the epidermis flaking off; stipules $0.4-0.6 \mathrm{~cm}$ long, \pm densely and minutely appressedpuberulous, caducous or subpersistent. Figs cauliflorous, solitary; peduncle $0.2-0.3$ cm long; basal bracts 1.5-2.5 mm long, persistent; receptacle depressed-globose, 

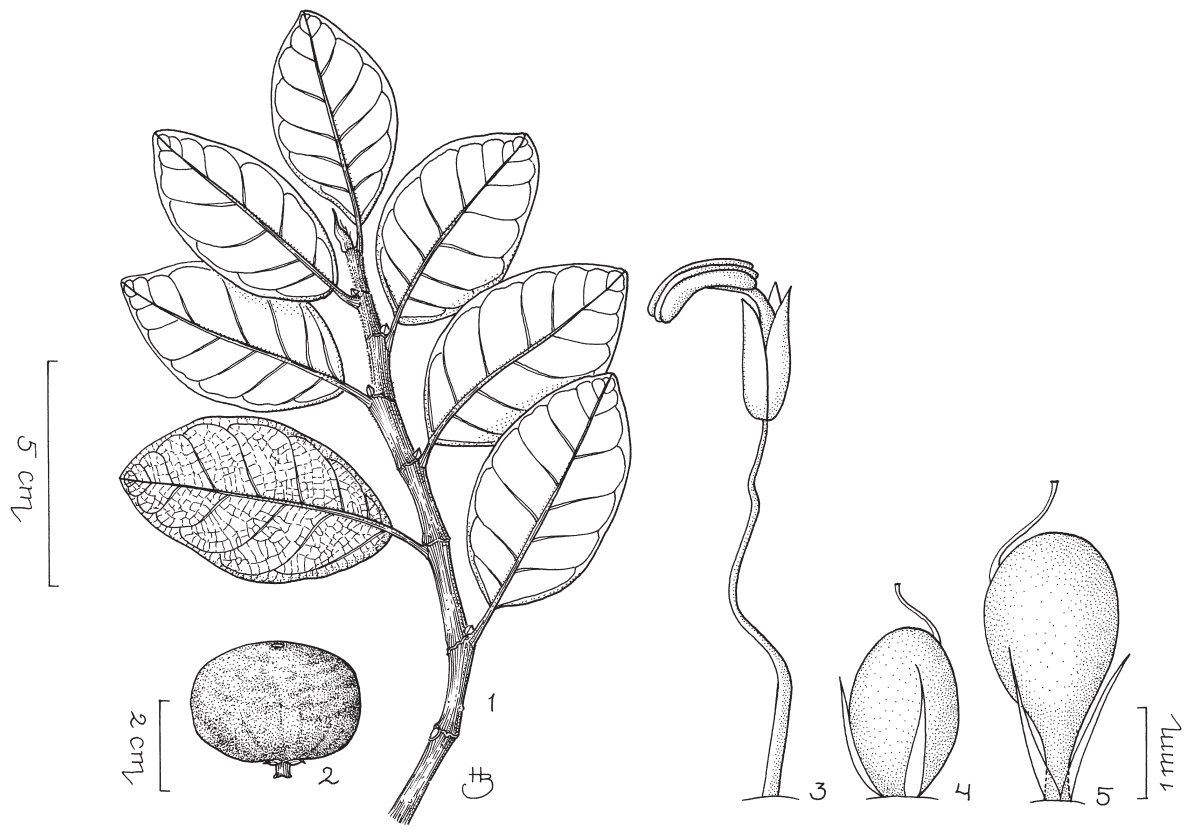

Fig. 1. Ficus cavernicola C.C. Berg. 1. Leafy twig; 2. fig; 3. staminate flower; 4, 5. short-styledpistillate flowers (all Chew \& Corner RSNB 4766).

c. $3.5 \mathrm{~cm}$ diam. when dry, substipitate, sparsely brownish appressed-puberulous, colour at maturity unknown, apex convex, ostiole c. $2 \mathrm{~mm}$ diam., flat; internal hairs sparse and short. Tepals red. Stamen 1.

Distribution - Malesia: Borneo (Sabah: Mt Kinabalu).

Habitat - Montane forest; at c. $2000 \mathrm{~m}$.

Note - This species resembles F.cataupi (from the Philippines) in the small laminas and the short petioles, but it differs in the numerous lateral veins, impressed above, and in the depressed-globose fig receptacles.

Ficus colobocarpa (Corner) C.C. Berg, stat. nov.

Based on: Ficus pantoniana King var. colobocarpa Diels ex Corner (1960) 8; (1962) 388, f. 2; (1965) 53. - Type: Clemens et al. 2124 (holo B), Papua New Guinea, Prov. Morobe, Quembung Mission, 25 March 1936.

Root-climber. Branchlets drying dark brown. Leafy twigs 2-3 mm thick, brown (sub) strigillose. Leaves distichously alternate; lamina oblong, $4-12$ by $1.5-4 \mathrm{~cm}$, symmetric, coriaceous, apex (sub)acuminate, base equilateral, rounded to subcordate, margin entire; upper surface brown strigillose or glabrous, lower surface (sub)strigillose to subsericeous on the main veins, hairs on the smaller veins pointing towards the apex of the lamina; cystoliths on both sides; midrib prominent above, raised as a narrow ridge in an impression, lateral veins 4 or 5 pairs, the basal pair up to c. $1 / 3$ the length of the lamina, faintly branched, tertiary venation (sub) scalariform, the smaller veins 
prominent beneath; waxy glands in the axils of the basal pair; petiole $0.5-1 \mathrm{~cm}$ long, brown (sub)strigillose, the epidermis persistent; stipules c. $0.5 \mathrm{~cm}$ long, brownish (sub) sericeous, caducous. Figs axillary (?), solitary or in pairs (?), sessile; basal bracts c. 1-3 mm long, caducous (or subpersistent?); receptacle ellipsoid, 0.8-1 cm diam. when dry, $0.4-0.5 \mathrm{~cm}$ long stipitate, the stipes yellowish (sub) sericeous, colour at maturity unknown, apex \pm convex or flat, ostiole $0.5-1 \mathrm{~mm}$ diam., sunken or prominent, surrounded by a low rim; wall rather thick; internal hairs absent. Tepals red.

Distribution - Malesia: New Guinea.

Ecology - Forest; at 600-700 m.

Notes -1 . This species shows similarities to $F$. ovatacuta and $F$. sageretina. It differs from both in the persistent epidermis of the petiole, the abundant presence of hairs also on the smaller veins of the lamina beneath, and the ellipsoid fig receptacle, being only hairy on the stipe.

2. The position of the figs on the plant is uncertain, because the figs of the single collection known of the species are detached.

Ficus disticha Blume (1825) 458

\section{a. subsp. disticha}

Including: F. callicarpides Corner (1960) 17.

Lamina symmetric (or asymmetric), usually subobovate to obovate, usually up to $5 \mathrm{~cm}$ long, apex rounded to obtuse, base cuneate to obtuse, margin mostly clearly revolute; lateral veins (2-)3-6 pairs, basal pair usually well-developed, up to $1 / 2$ the length of the lamina (subtrinervate). Figs axillary (or just below the leaves). Staminate flowers scattered among the pistillate ones.

Distribution - Myanmar, Thailand, Malay Peninsula, Sumatra, Java, Borneo, Philippines, and Celebes.

Habitat - Montane forest (often mossy forest) and lowland forest (in Borneo often peat forest); at altitudes up to c. $2200 \mathrm{~m}$.

b. subsp. calodictya (Summerh.) C.C. Berg, comb. \& stat. nov.

Based on: Ficus calodictya Summerh., J. Arnold Arbor. 10 (1929) 149. - Type: Brass 1360 (holo A), Papua New Guinea, 'Gulf Division', Cupola, 1 April 1926.

Including: F. agapetoides Diels (1935) 222; F. calodictya Summerh. var. gamophylla Corner (1960)

18; F. agapetoides var. solomonensis Corner (1960) 18; F. meiocarpa Diels (1935) 221; F. phatnophylla Diels var. meiophylla (Diels) Corner (1960) 18.

Lamina symmetric, varying from subobovate to subovate to elliptic to oblong to (sub)ovate or to suborbicular, up to $7 \mathrm{~cm}$ long, apex rounded to obtuse to subacute to shortly and bluntly acuminate, base cuneate to rounded to subcordate, margin often slightly revolute; lateral veins (3-)4-7(-8) pairs, the basal pair often poorly developed, often up to 1/4 the length of the lamina (mostly not subtrinervate). Figs also below the leaves, on minute spurs, sometimes clustered. Staminate flowers near the ostiole.

Distribution - Moluccas (Halmahera, Ceram, Ternate), New Guinea, and New Britain; extending to the Solomon Islands.

Habitat - Forest; at altitudes up to $2000 \mathrm{~m}$. 


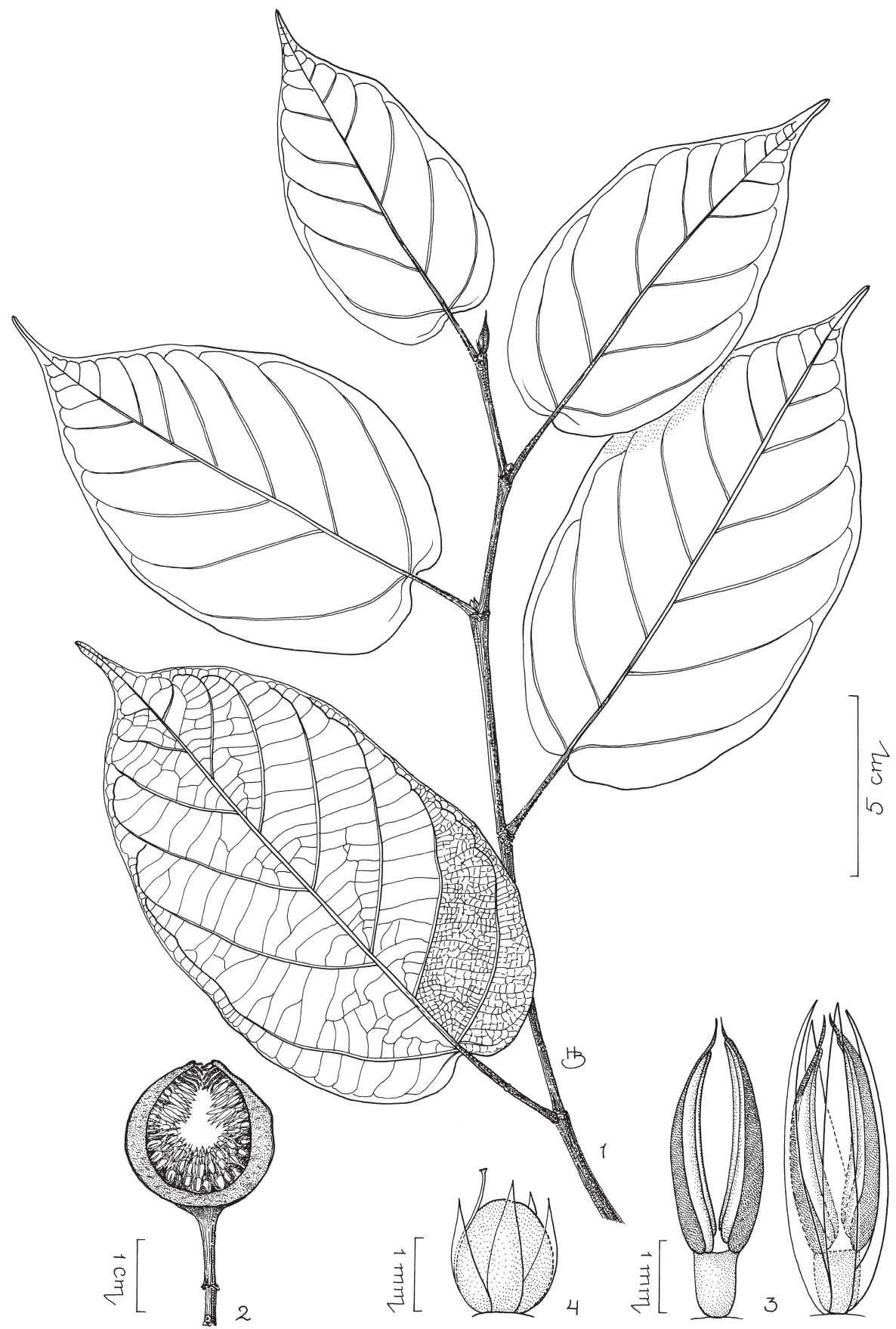

Fig. 2. Ficus jacobsii C.C. Berg. 1. Leafy twig; 2. fig; 3 . staminate flower and stamens; 4 . short-styled pistillate flowers (all Schodde 1552). 
Ficus jacobsii C.C. Berg, spec. nov. - Fig. 2

Fico baeuerleinii et F. odoardii simili, indumento satis sparso praecipue pilis setosis prurientibus distincta. - Typus: Jacobs 9419 (holo LAE; L), Papua New Guinea, Mt Bosavi, northern side, 900-1000 m, 24 Oct. 1973.

Root-climber. Branchlets drying brown to blackish. Leafy twigs 2-3 mm thick, solid, sparsely minutely puberulous to subhispidulous and sparsely setose-strigose (with irritant hairs). Leaves distichously alternate; lamina ovate to subovate, $9-17$ by 4-9 $\mathrm{cm}$, symmetric, coriaceous, apex acuminate or apiculate, base equilateral, cordate, margin entire, flat or revolute towards the base; upper surface glabrous, lower surface sparsely setose-strigose (with irritant hairs) or also sparsely hispidulous on the main veins; cystoliths on both surfaces; midrib slightly prominent above, lateral veins 6-8 pairs, the basal pair up to c. 1/4-1/3 the length of the lamina, branched, tertiary venation scalariform, the smaller veins slightly prominent to flat beneath; waxy glands in the axils of the basal pair and of some other lateral veins or also in the axils of branches of lateral veins; petiole 1-1.8 cm long, glabrous, the epidermis flaking off; stipules 0.8-1 cm long, minutely brown puberulous and sparsely setose-strigose (with irritant hairs), mainly at the base, caducous. Figs axillary or just below the leaves (?), solitary; peduncle c. $0.5 \mathrm{~cm}$ long; basal bracts $2-5 \mathrm{~mm}$ long, caducous; receptacle subglobose, 1.5-5 (or -6.5 ?) $\mathrm{cm}$ diam. when dry, up to $6.5 \mathrm{~cm}$ diam. when fresh, 1-1.2 $\mathrm{cm}$ long stipitate, setose, \pm orange at maturity, wall $(3-12 \mathrm{~mm})$ thick and hard, apex convex, ostiole $2-5 \mathrm{~mm}$ diam., slightly to deeply sunken; internal hairs very sparse. Tepals red. Staminate flowers numerous.

Distribution - New Guinea (eastern).

Habitat - Montane and submontane forest; altitudes between c. 1000 and $2200 \mathrm{~m}$.

Notes -1 . This species resembles $F$. baeuerlenii and $F$. odoardii, in the shape and dimensions of the leaves and the figs. It is distinct in the rather sparse indumentum, mainly consisting of setose and irritant hairs.

2 . The gall figs of the two collections examined differ considerably in their dimensions: $1.5-2 \mathrm{~cm}$ or $4.5-6.5 \mathrm{~cm}$ diameter.

3. The description is also based on Schodde $1552(\mathrm{~L})$.

Ficus jimiensis C.C. Berg, spec. nov. - Fig. 3

Fico nasutae similis, e.g., stipulis exceptis omnibus partibus glabris, syconiis maioribus distincta. - Typus: Millar NGF 37689 (holo LAE; L, according to label duplicates sent to A, BO, BRI, CANB, K, and SING), Papua New Guinea, Prov. Western Highland, Subprov. Hagen, on road to Jimi, 4400 ft., 9 July 1968.

The species includes: F. nasuta Summerh. var. glabrata Corner (1960) 19. - Type: J. Clemens 1170 (holo L), Papua New Guinea, Morobe Province, 'Sattelberg', Dec. 1935.

Root-climber. Branchlets drying dark brown. Leafy twigs 2-8 $\mathrm{mm}$ thick, hollow, glabrous. Leaves distichously alternate; lamina cordiform (to elliptic), (4.5-)8-22 by (2.5-)5-16 cm, symmetric, (sub)coriaceous, apex (sub)acuminate, base equilateral, cordate (to rounded), margin entire, flat to slightly revolute; both surfaces glabrous; cystoliths only beneath; midrib flat to slightly impressed above, lateral veins 4 or 5 (or 6 ) 


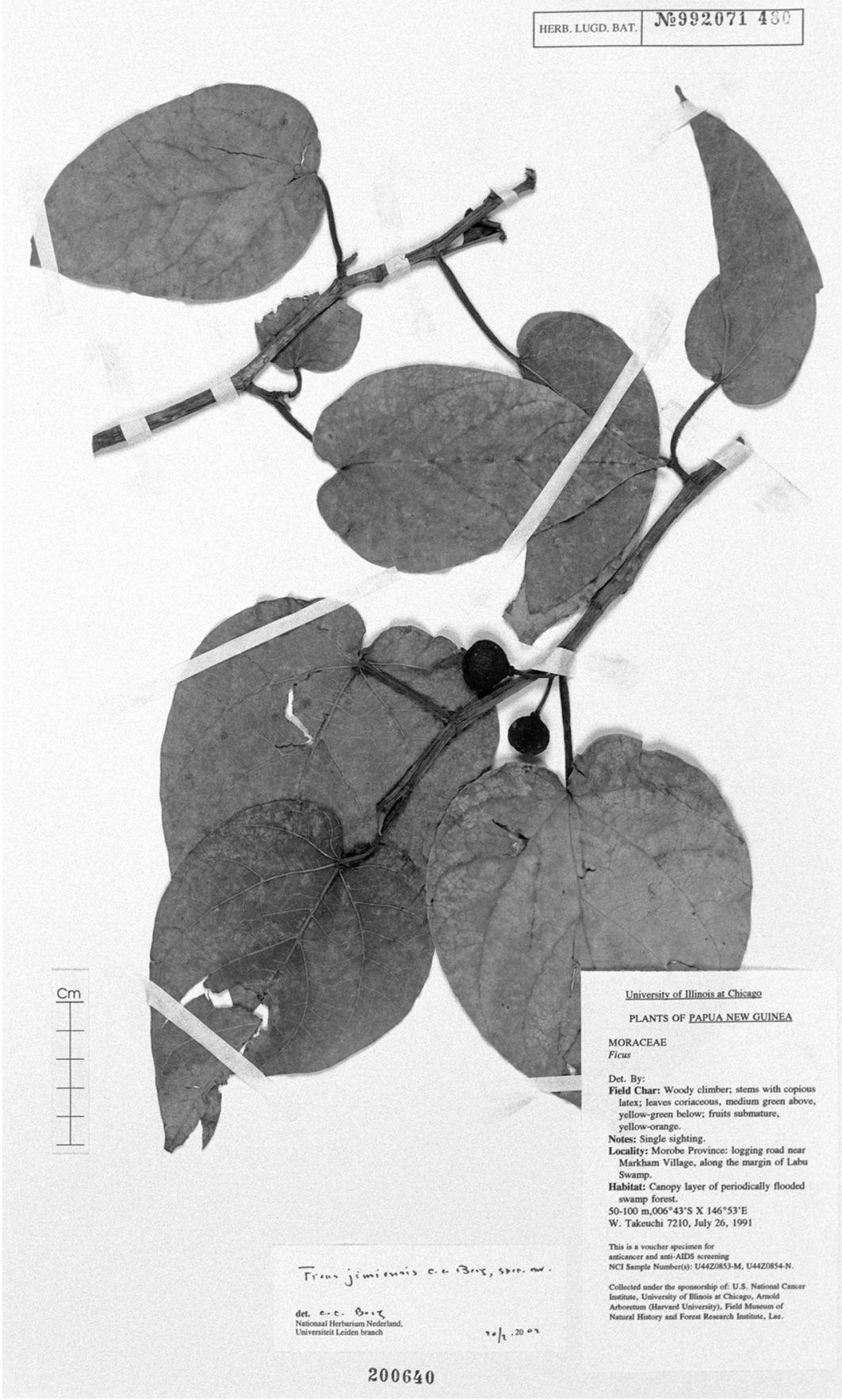

Fig. 3. Ficus jimiensis C.C. Berg. Leafy twigs with figs (W. Takeuchi 7210, L), Papua New Guinea, Morobe Province, Markham Village, 26 July 1991. 
pairs, the basal pair up to c. $1 / 2$ the length of the lamina, branched, the other lateral veins often branched or furcate far from the margin, tertiary venation scalariform, the smaller veins slightly prominent beneath; waxy glands in the axils of the basal pair and of some other lateral veins or also in the axils of branches of lateral veins; petiole (1.5-) 2.5-7.5 cm long, glabrous, the epidermis flaking off; stipules $0.5-1.5 \mathrm{~cm}$ long, brownish to whitish appressed-puberulous to subsericeous, caducous. Figs axillary, in pairs or solitary; peduncle $0.8-3 \mathrm{~cm}$ long; basal bracts $2-3 \mathrm{~mm}$ long, persistent, often spreading to slightly deflexed; receptacle subglobose, (1.2-) $1.5-2.5 \mathrm{~cm}$ diam. when dry, $1.5-3 \mathrm{~cm}$ diam. when fresh, non-stipitate or substipitate, glabrous, yellow to orange to red at maturity, apex \pm umbonate, ostiole c. $1 \mathrm{~mm}$ diam., slightly prominent; internal hairs sparse and short or absent. Tepals red. Stamens 2.

Distribution - New Guinea (eastern, incl. New Britain)

Habitat - Lowland and montane forest; at altitudes up to c. $1900 \mathrm{~m}$.

Notes -1 . This species, initially recognized as a variety of $F$. nasuta Summerh., is here treated as a distinct species. It differs from $F$. nasuta (confined to the Solomon Islands), e.g., in the absence of indumentum on all parts, except for the stipules, the larger (normally $1.5-2.5 \mathrm{~cm}$ diam.) and glabrous figs, in $F$. nasuta up to c. $1.2 \mathrm{~cm}$ diam. when dry and mostly densely hairy. Moreover, the lamina is in average longer, cordiform to ovate with a deeply cordate to subcordate base (in F. nasuta elliptic to broadly ovate with an obtuse to subcordate base), the petioles are mostly longer than $3 \mathrm{~cm}$ (in $F$. nasuta usually shorter than $3 \mathrm{~cm}$ ), and the internal hairs are sparse or absent (but abundant in F. nasuta).

2. The description is also based on Carr 14321 (L) and 14462 (L), Croft et al. LAR 68626 (L), Foreman et al. NGF 45765 (L), LAE 60011 (L), and LAE 60109 (L), Henty et al. NGF 41566 and 49494 (L), Vandenberg et al. NGF 42042 (L), Ridsdale NGF 33959 and 36715 (L), Schramm BW 9315 (L) Streimann et al. NGF 39081 (L), Vandenberg et al. NGF 42042 (L), Womersley et al. NGF 19328 (L) and NGF 37253 (L).

Ficus sohotonensis C.C. Berg, spec. nov. - Fig. 4

Fico apiocarpae et $F$.peninsulae similis, in venis lateralibus numerosis, stipulis persistentibus carina conspicue pilosa distincta. - Typus: Guterriez et al. 622 (holo L), Philippines, Samar, Mt Sohoton, April 1970.

Root-climber. Branchlets drying brown; scars of the leaves prominent. Leafy twigs 2-7 mm thick, solid, brownish puberulous to subtomentose to subvillous. Leaves in lax spirals to distichously alternate; lamina oblong to lanceolate, $11-31$ by $3-8.5 \mathrm{~cm}$, symmetric, coriaceous, apex acuminate, base (almost) equilateral, obtuse to narrowly truncate, margin entire, \pm revolute; upper surface glabrous, lower surface (sparsely) subtomentose to pilose on the (main) veins, tessellate when dry; cystoliths only beneath; midrib slightly prominent to flat above, lateral veins $10-14$ pairs, the basal pair up to $1 / 20-1 / 10$ the length of the lamina, poorly developed, running rather close to the margin, (faintly) branched or unbranched, the other lateral veins often branched or furcate, tertiary venation (sub)scalariform, the smaller veins (almost) flat beneath, the areoles \pm clearly brownish when dry; waxy glands in the axils of the basal pair or 


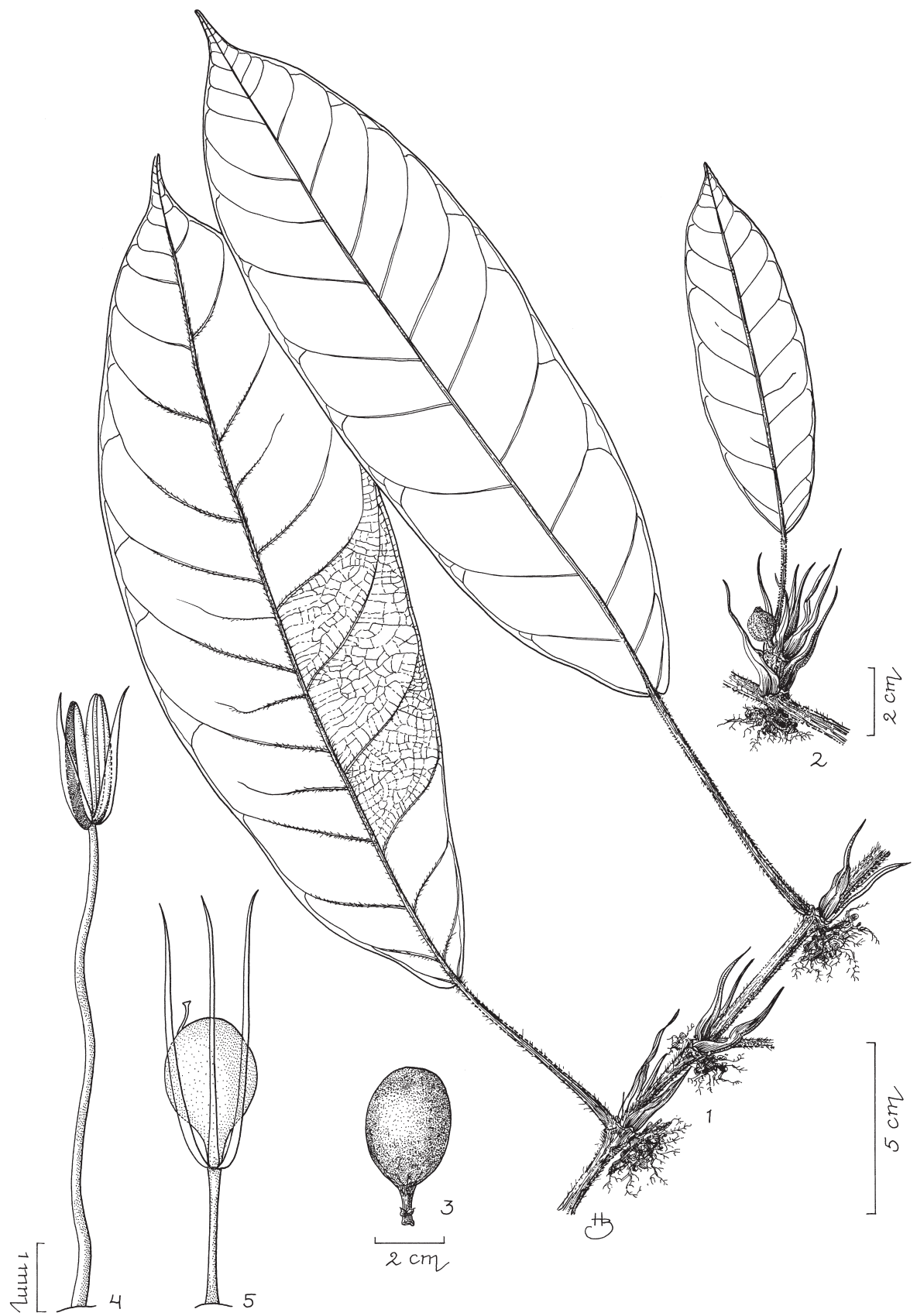

Fig. 4. Ficus sohotonensis C.C. Berg. 1. Leafy twig with long internodes; 2. leafy twig with short internodes and young fig; 3. fig; 4. staminate flower; 5. short-styled pistillate flower (all Gutierrez et al. 622). 
also of some other lateral veins; petiole $2-7.5 \mathrm{~cm}$ long, subtomentose to subvillous, the epidermis flaking off; stipules $1.5-2.5 \mathrm{~cm}$ long, sparsely, but along the margin densely minutely appressed-puberulous, and on the keel and the apex brown strigillose, (sub)persistent. Figs on short leafy twigs, terminated with a tuft of persistent stipules, solitary; peduncle $0.1-0.2 \mathrm{~cm}$ long; basal bracts c. $2 \mathrm{~mm}$ long, persistent; receptacle ellipsoid, 2-3.5 $\mathrm{cm}$ diam. when dry, up to $0.5 \mathrm{~cm}$ long stipitate, sparsely brownish puberulous to substrigillose, reddish at maturity, apex convex, ostiole c. $2 \mathrm{~mm}$ diam., \pm prominent; internal hairs absent. Tepals red. Stamens 1 (or 2).

Distribution - Philippines (Samar).

Habitat - Forest; at low altitudes.

Note - This species belongs to a set of species including F. apiocarpa and F. peninsula. It differs from both in the numerous lateral veins, by the persistent stipules with a conspicuously hairy keel, and probably also the figs, not born in leaf axils.

\section{Ficus submontana C.C. Berg, spec.nov. - Fig. 5}

Fico peninsulae similis, e.g., venis lateralibus numerosioribus, syconii receptaculo dense piloso apice protracto distincta. - Typus: De Vogel 5272 (holo BO; iso L), Indonesia, Celebes, Mt Roroka Timbu, c. 80 km SSE of Palu, 1150 m, 10 May 1979.

Root-climber. Branchlets drying brown; scars of the petioles prominent. Leafy twigs 3-7 mm thick, solid, whitish puberulous to subtomentose. Leaves in lax spirals to distichously alternate; lamina oblong to elliptic to subovate, 9-21 by $4.5-10 \mathrm{~cm}$, symmetric, coriaceous, apex acuminate, base equilateral or slightly inequilateral, cuneate to rounded, often subauriculate, margin entire, revolute; upper surface glabrous, lower surface glabrous or very sparsely subtomentose on the midrib, tessellate when dry; cystoliths only beneath; midrib flat to slightly impressed above, lateral veins 8-10 pairs, the basal pair up to c. 1/10-1/5 the length of the lamina, poorly developed, running rather close to the margin, (faintly) branched or unbranched, the other lateral veins often branched or furcate, tertiary venation (sub)scalariform, the smaller veins (almost) flat beneath, the areoles \pm clearly brownish when dry; waxy glands in the axils of the basal pair or also of some other lateral veins; petiole $1.5-3.5 \mathrm{~cm}$ long, sparsely puberulous to subtomentose to glabrous, the epidermis flaking off; stipules 1.5-2.2 $\mathrm{cm}$ long, densely minutely appressed-puberulous, caducous. Figs axillary, solitary or in pairs; peduncle $0.1-0.2 \mathrm{~cm}$ long; basal bracts c. $2 \mathrm{~mm}$ long, persistent; receptacle ellipsoid, c. 1.5-2.5 cm diam. when dry, substipitate, densely brownish puberulous to subvelutinous, reddish (?) at maturity, apex protracted, c. 1-2 mm diam., \pm prominent; internal hairs absent. Tepals red. Stamen 1.

Distribution - Celebes (northern and central).

Habitat - Submontane forest; at altitudes of 1000-1200 m.

Notes -1 . This species is closely related to $F$. peninsula (from the Philippines), from which it differs in the more numerous lateral veins, of which the basal pair is usually poorly developed and up to c. 1/5 the length of the lamina, and in the densely hairy fig receptacle with a protracted apex. Considering the nature of the differences between $F$. peninsula and $F$. apiocarpa, it appears to be correct to recognize also $F$. submontana as a distinct species.

2. The description is also based on De Vogel 2483 and 5606 (L). 


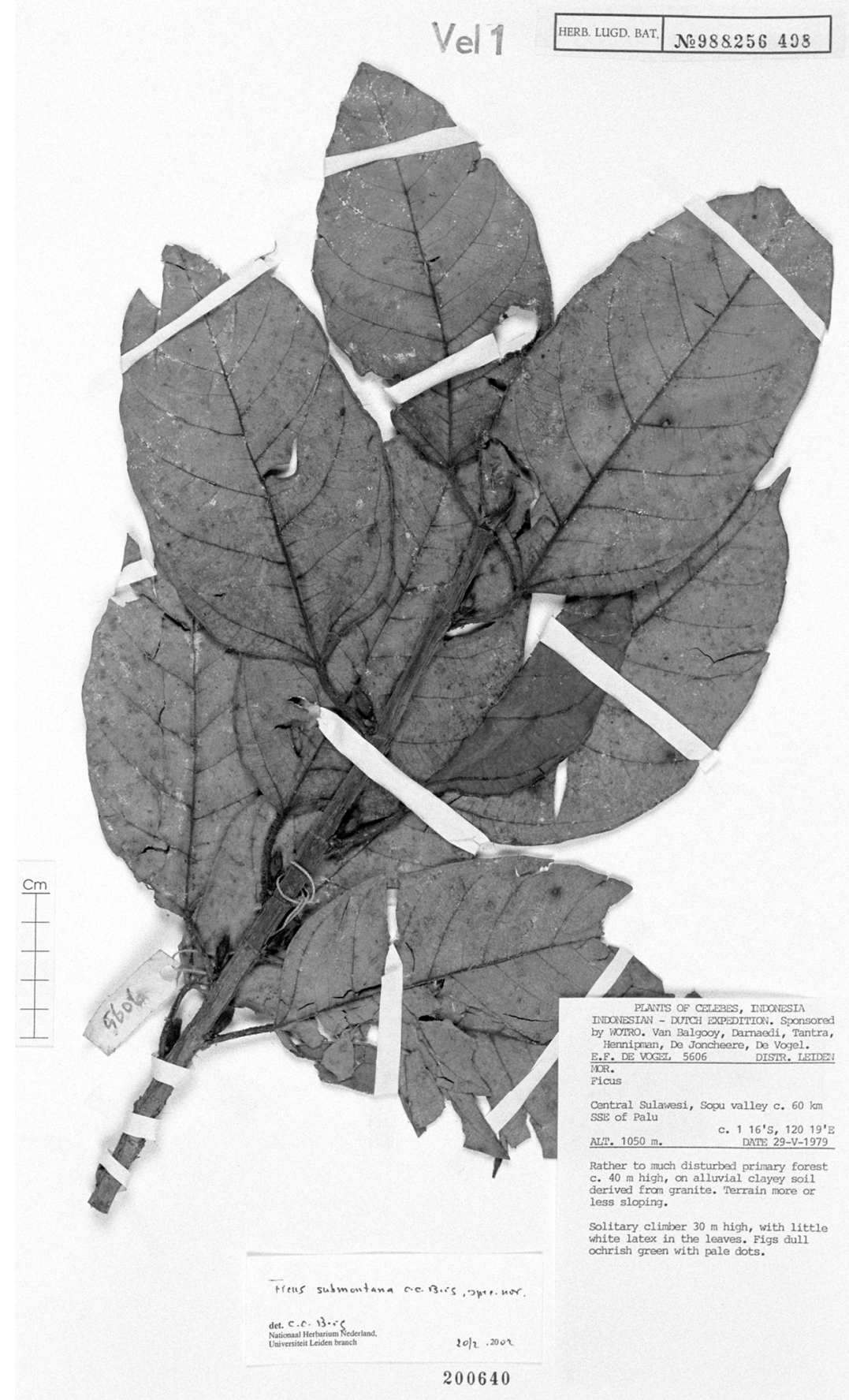

Fig. 5. Ficus submontana C.C. Berg. Leafy twigs with young figs (De Vogel 5606, L), Indonesia, Sulawesi, c. 60 km SSE of Palu, 1050 m, 29 May 1979. 


\section{KEY TO THE SPECIES OF SUBGENUS SYNOECIA}

1a. Leafy twigs with pairs of subnodal waxy glands below (the scars of) the petioles. - Sumatra, Malay Peninsula, Java, Borneo . . . . . . . . . . . 60. F. laevis

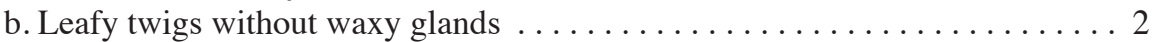

2a. Lower surface of the lamina foveolate with deep stomatal pits and the areoles surrounded by very prominent veinlets; the midrib of the lamina not reaching the apex; cultivated

62. F. pumila

b. Lower surface of the lamina not foveolate or, if foveolate, then the stomatal pits shallow, surrounded by slightly prominent to almost flat veinlets, often bearing short hairs \pm covering the stomatal pits; indigenous $\ldots \ldots \ldots \ldots \ldots \ldots$

3a. Lower surface of the lamina foveolate (the areoles surrounded by a rim) or tessellate (the areoles brownish when dry, usually surrounded by paler coloured tissue) 4

b. Lower surface of the lamina neither foveolate nor clearly tessellate . . . . 37

4a. Lower surface of the lamina foveolate $\ldots \ldots \ldots \ldots \ldots \ldots \ldots \ldots$

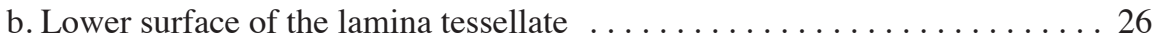

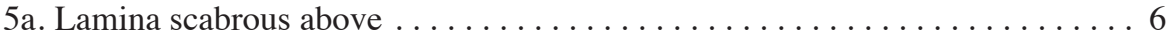

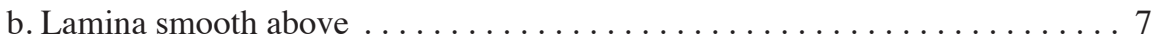

6a. Petiole $0.5-1.5 \mathrm{~cm}$ long; lamina $4-11 \mathrm{~cm}$ long. - Java. . . 23. F. trachycoma

b. Petiole 1.5-3 cm long; lamina 10-21 cm long. - Borneo . . 24. F. tulipifera

7a. Petiole $0.2-1 \mathrm{~cm}$ long; stipules $0.3-1 \mathrm{~cm}$ long; lamina often shorter than $10 \mathrm{~cm} 8$

b. Petiole 1-4 or 4-13 cm long; stipules $(0.5-) 1-2(-4.5) \mathrm{cm}$ long and/or the lamina

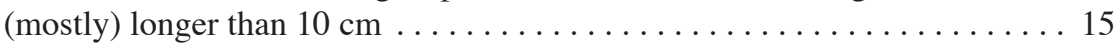

8a. Lamina asymmetric with 1 waxy gland in the axil of the basal lateral vein at the broad side of the lamina . . . . . . . . . . . . . . . . . 9

b. Lamina symmetric (or slightly asymmetric at the base) with waxy glands in the axils of both basal lateral veins or absent . . . . . . . . . . . . 10

9a. Main veins of the lamina impressed above; internal hairs absent. - Sumatra, Malay Peninsula, Borneo ................ 17.F. ruginervia

b. Main veins of the lamina almost flat to slightly prominent, or the midrib slightly impressed above; internal hairs abundant. - Widespread ... . 16. F. punctata

10a. Figs axillary in pairs or clustered (also on the older wood), the receptacle $0.2-0.6$ $\mathrm{cm}$ diam. when dry; areoles without indumentum on the rims . . . . . . 11

b. Figs cauliflorous, the receptacle $1-10 \mathrm{~cm}$ diam. when dry, areoles mostly with

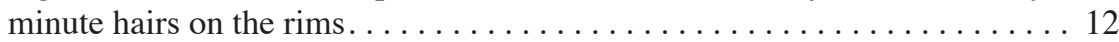

11a. Indumentum of leafy twigs pale brown to greyish; lamina 3-11 cm long; fig receptacle $0.4-0.6 \mathrm{~cm}$ diam. when dry. - Sumatra, Malay Peninsula . . . . . . .

27. F. araneosa

b. Indumentum of leafy twigs brown(ish); lamina 1-4.5 cm long; fig receptacle $0.2-0.3 \mathrm{~cm}$ diam. when dry. - Sumatra, Malay Peninsula . . 32. F. excavata

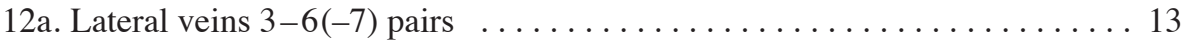

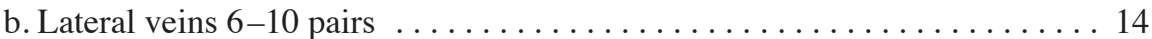

13a. Fig receptacle $(1.5-) 3-5(-10) \mathrm{cm}$ diam. when dry, the basal bracts $3-5 \mathrm{~mm}$ long; apex of the lamina minutely retuse. - Widespread . . . . . 16. F. punctata

b. Fig receptacle 1-2 $\mathrm{cm}$ diam. when dry, the basal bracts $2-3 \mathrm{~mm}$ long; apex of

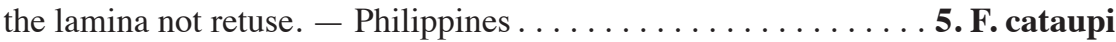


14a. Basal lateral veins up to 1/6-1/4 the length of the lamina, (faintly) branched; fig receptacle ellipsoid, the basal bracts 4-6 mm long. - Borneo 3. F. barba-jovis

b. Basal lateral veins up to $1 / 10-1 / 6$ the length of the lamina, unbranched; fig receptacle depressed-globose, the basal bracts $1.5-2.5 \mathrm{~mm}$ long. - Borneo

6. F. cavernicola

15a. Figs axillary or just below the leaves, often clustered, the receptacle $0.4-0.8 \mathrm{~cm}$ diam. when dry; rims of the areoles without hairs $\ldots \ldots \ldots \ldots \ldots \ldots$

b. Figs mostly cauliflorous and/or the receptacle more than $1 \mathrm{~cm}$ diam. when dry, or if axillary and less than $1 \mathrm{~cm}$ diam. when dry, then the rims of the areoles with hairs (and occurring in New Guinea) . . . . . . . . . . . . . 17

16a. Basal lateral veins of the lamina up to $1 / 5-1 / 3$ the length of the lamina; basal bracts (sub) persistent. - Borneo ........... 49. F. supperforata

b. Basal lateral veins of the lamina up to $1 / 3-1 / 2$ the length of the lamina; basal bracts caducous. - Sumatra, Java, Borneo . . . . . . . . . . 38. F. lanata

17a. Petiole (3-)4-13 cm long and stipules $1.5-5 \mathrm{~cm}$ long; figs cauliflorous. - Bor-

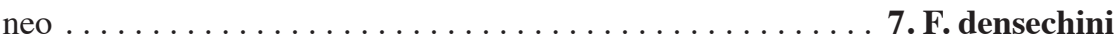

b. Petiole 1-4 cm long, if up to $5 \mathrm{~cm}$ long, then the stipules $1-1.5 \mathrm{~cm}$ long, or if up

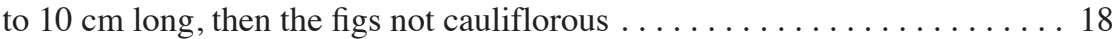

18a. Lamina glabrous on the veins beneath . . . . . . . . . . . . . . . 19

b. Lamina hairy on the veins beneath, often only sparsely so . . . . . . . 21

19a. Lateral veins 3-6 pairs; lamina 2-12 cm long. - Widespread . 16. F. punctata

b. Lateral veins $6-10$ pairs; lamina mostly longer than $10 \mathrm{~cm} \ldots \ldots \ldots \ldots 20$

20a. Midrib of the lamina slightly prominent to flat above; figs cauliflorous. - Bor-

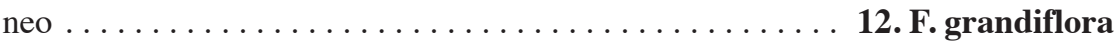

b. Midrib of the lamina \pm impressed above; figs axillary. - New Guinea . . . . . . .

19. F. scratchleyana

21a. Lateral veins 3-6 pairs, the midrib slightly prominent above. - Widespread . .

16. F. punctata

b. Lateral veins $6-12$ pairs, the midrib often \pm impressed above . . . . . 22

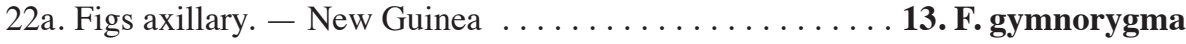

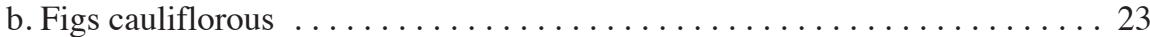

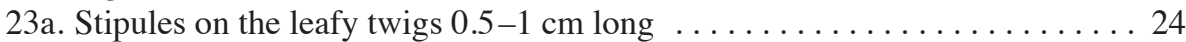

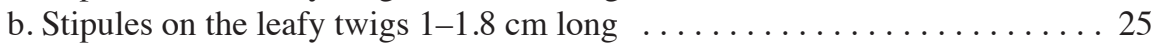

24a. Venation of the lamina \pm impressed above. - Borneo . . . 18. F. sarawakensis

b. Venation flat or the midrib (at least its upper part) slightly prominent above. - Borneo ...................... 24. F. tulipifera

25a. Lamina 9-21 cm long, \pm asymmetric, at least at the base; fig receptacle brown

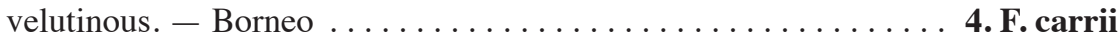

b. Lamina 7-12 cm long, (almost) symmetric; fig receptacle glabrous. - Sumatra

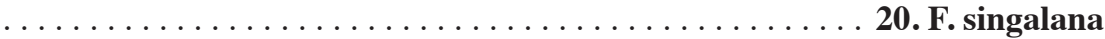

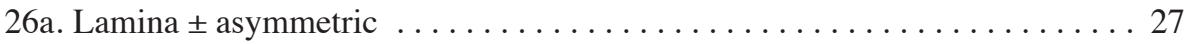

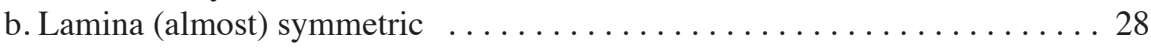

27a. Lamina 4-9 cm long; petiole $0.5-1.5(-2) \mathrm{cm}$ long; fig receptacle c. $1 \mathrm{~cm}$ diam.

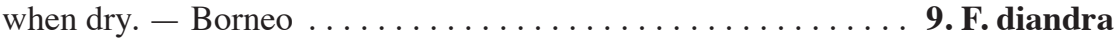

b. Lamina 1-3.5 cm long; petiole $0.2-0.4 \mathrm{~cm}$ long; fig receptacle $0.2-0.3 \mathrm{~cm}$ diam. when dry. - Widespread

10 F. disticha 
28a. Lamina usually $10-20(-30) \mathrm{cm}$ long, the petiole $1-7.5 \mathrm{~cm}$ long, the stipules mostly longer than $1 \mathrm{~cm}$, and/or the tertiary venation mostly (sub) scalariform .

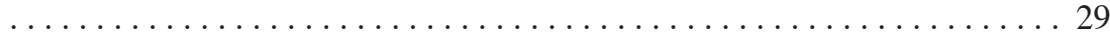

b. Lamina usually less than $10 \mathrm{~cm}$ long, the petiole and/or the stipules mostly up to $1 \mathrm{~cm}$, and the tertiary venation distinctly reticulate $\ldots \ldots \ldots \ldots 33$

29a. Lateral veins 10-14 pairs, the basal pair up to $1 / 10$ the length of the lamina. - Philippines

21. F. sohotonensis

b. Lateral veins (3-)4-10 pairs, the basal pair well-developed, more than up to $1 / 10$

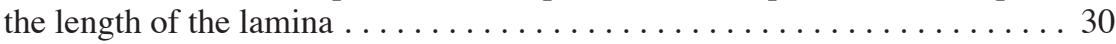

30a. Fig receptacle $0.6-1 \mathrm{~cm}$ diam. when dry. - Widespread . . . 1. F. allutacea

b. Fig receptacle $1.5-2.5 \mathrm{~cm}$ diam. when dry $\ldots \ldots \ldots \ldots \ldots \ldots \ldots \ldots$

31a. Lateral veins $8-10$ pairs, the basal pair $1 / 10-1 / 5$ the length of the lamina; fig receptacle densely brownish hairy, the apex distinctly protracted. - Celebes . .

22. F. submontana

b. Lateral veins (3-)4-8 pairs, the basal pair (1/5-) $1 / 4-1 / 2(-2 / 4)$ the length of the lamina; fig receptacle sparsely and/or minutely white puberulous or glabrous, the

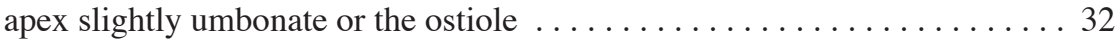

32a. Lateral veins (3-)4-6 pairs, the basal pair 1/3-1/2(-3/4) the length of the lamina, distinctly branched. - Sumatra, Malay Peninsula, Borneo . . 2. F. apiocarpa

b. Lateral veins $6-8$ pairs, the basal pair $(1 / 5-) 1 / 4-1 / 3$ the length of the lamina, unbranched or faintly branched. - Philippines. . . . . . 14. F. peninsula

33a. Acumen of the lamina shortly mucronate. - New Guinea 15. F. phatnophylla

b. Acumen (or apex) of the lamina minutely retuse . . . . . . . . . . . 34

34a. Fig receptacle $0.3-0.6(-0.8) \mathrm{cm}$ diam. when dry, the basal bracts usually caducous; lamina often broadest above or below the middle. - Widespread 10. F. disticha

b. Fig receptacle $0.7-1.2(-1.5) \mathrm{cm}$ diam. when dry, the basal bracts mostly persistent; lamina broadest in the middle ................... 35

35a. Basal lateral veins up to $1 / 4-1 / 3$ the length of the lamina; basal bracts $1.5-3 \mathrm{~mm}$

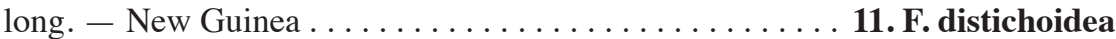

b. Basal lateral veins up to $1 / 10-1 / 3$ the length of the lamina; basal bracts c. $1.5 \mathrm{~mm}$

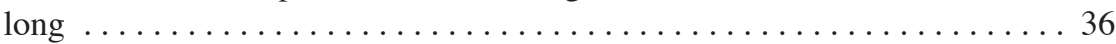

36a. Petiole $1.5-2.5 \mathrm{~mm}$ thick; margin of the lamina distinctly revolute. - Borneo .

8. F. detonsa

b. Petiole $1-1.5 \mathrm{~mm}$ thick; margin of the lamina slightly revolute towards the base.

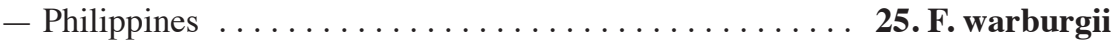

37a. Indumentum partly consisting of uncinate hairs. - Widespread .44. F. recurva

b. Indumentum without uncinate hairs $\ldots \ldots \ldots \ldots \ldots \ldots \ldots \ldots \ldots \ldots$

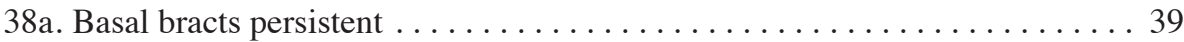

b. Basal bracts caducous .......................... 62

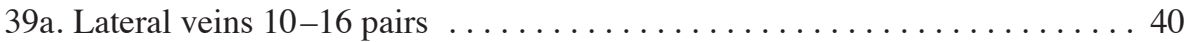

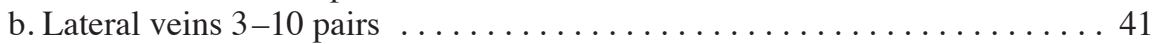

40a. Fig receptacle $0.4-0.5 \mathrm{~cm}$ diam. when dry; figs mostly clustered. - Borneo ..

b. Fig receptacle 1-3 cm diam. when dry; figs mostly solitary. - Malay Peninsula

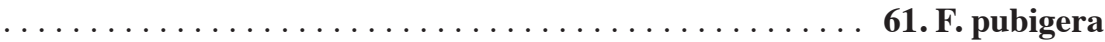

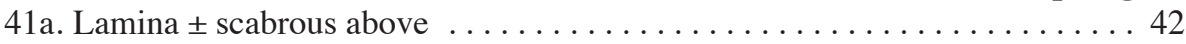

b. Lamina smooth above ........................ 43 
42a. Basal lateral veins c. $1 / 2-2 / 3$ the length of the lamina; indumentum of the lower surface of the lamina brown. - Widespread ........ 59. F. trichocarpa

b. Basal lateral veins up to c. 1/2 the length of the lamina; indumentum of lower surface of the lamina dark brown. - Philippines . . . . . 55. F. perfulva

43a. Lamina \pm scabrous beneath by very sparse and/or minute (cystolith) hairs. - Borneo

45. F. sabahana

b. Lamina smooth beneath, or if scabridulous, then distinctly hairy . . . . . . . 44

44a. Lamina glabrous . . . . . . . . . . . . . . . 45 (see also 26-36)

b. Lamina hairy, at least beneath, at least sparsely so on the midrib . . . . . . . . .

47 (see also $26-36$ )

45a. Basal lateral veins up to c. $1 / 2$ the length of the lamina; lamina mostly $10-20 \mathrm{~cm}$ long; fig receptacle $1.2-2.5 \mathrm{~cm}$ diam. when dry. - New Guinea . . . . . . . .

54. F. jimiensis

b. Basal lateral veins $1 / 8-1 / 4$ the length of the lamina; lamina usually up to $10 \mathrm{~cm}$ long; fig receptacle $0.3-0.8 \mathrm{~cm}$ diam. when dry . . . . . . . . . . . 46

46a. Acumen minutely retuse; fig receptacle $0.6-0.8 \mathrm{~cm}$ diam. when dry. - Borneo

8. F. detonsa

b. Acumen shortly mucronate; fig receptacle $0.3-0.4 \mathrm{~cm}$ diam. when dry. - New Guinea ................... phatnophylla

47a. Tertiary venation scalariform; lamina usually or often longer than $10 \mathrm{~cm}$, occa-

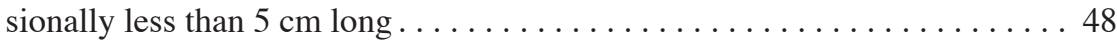

b. Tertiary venation reticulate or to subscalariform (with few, \pm irregular, transverse (and parallel) tertiary veins, in particular in relatively large leaves); lamina always or often less than $10 \mathrm{~cm}$ long, often less than $5 \mathrm{~cm}$ long and with 3-6 pairs of lateral veins, or, if usually longer than $10 \mathrm{~cm}$, then with $8-12$ pairs of lateral veins 57

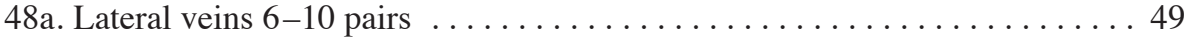

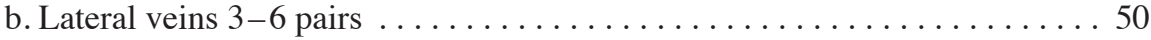

49a. Lateral veins and smaller veins of the lamina prominent beneath; hairs on the

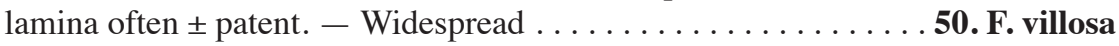

b. Lateral veins of the lamina slightly prominent, the smaller veins (almost) flat; hairs on the lamina appressed. - Widespread ........ 47.F. sagittata

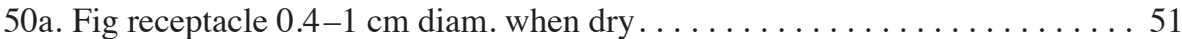

b. Fig receptacle $1-2.5 \mathrm{~cm}$ diam. when dry . . . . . . . . . . . . 54

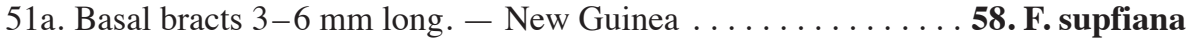

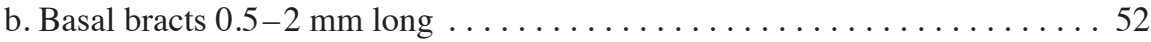

52a. Figs (sub) sessile, the receptacle glabrous. - Widespread . . . . . . . . .

44e. F. recurva var. urnigera

b. Figs $0.2-0.5 \mathrm{~cm}$ long, pedunculate, the receptacle hairy ... . . . 53

53a. Lower surface of the lamina densely hairy with dark brown hairs; leafy twigs 2-3 mm thick; fig receptacle $0.7-1 \mathrm{~cm}$ diam. when dry. - Philippines . . . . . . . .

55. F. perfulva

b. Lower surface of the lamina usually \pm sparsely hairy with pale brown hairs; leafy twigs $1-2 \mathrm{~mm}$ thick; fig receptacle $0.4-0.6 \mathrm{~cm}$ diam. when dry. - Philippines

51. F. bakeri

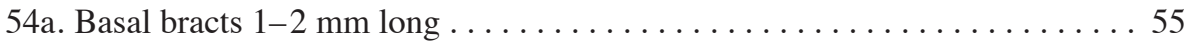

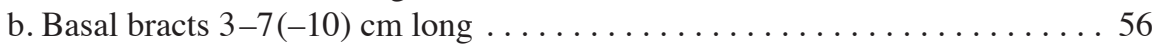


55a. Lamina sparsely hairy or glabrous beneath, flat above. - Sumatra, Malay Peninsula, Borneo

2. F. apiocarpa

b. Lamina densely hairy beneath, bullate above. - New Guinea

56. F. phaeobullata

56a. Basal lateral veins up to c. $1 / 2(-2 / 3)$ the length of the lamina; lamina sparsely

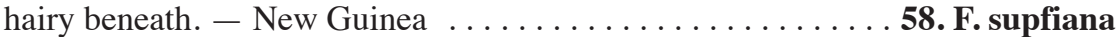

b. Basal lateral veins $2 / 3-3 / 4$ the length of the lamina; lamina densely hairy beneath.

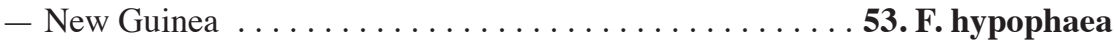

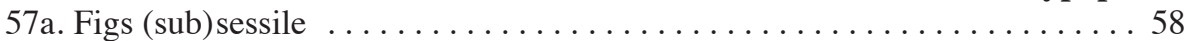

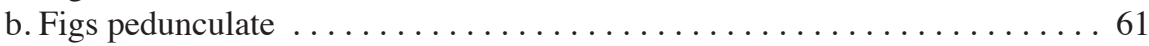

58a. Lateral veins $8-12$ pairs. - Malay Peninsula ... . . . . . 61. F. pubigera

b. Lateral veins $3-7$ pairs . . . . . . . . . . . . . . . . . . . . 59

59a. Leafy twigs pale brown to greyish floccose-tomentose; figs in pairs or often clustered in the leaf axils and below the leaves. - Sumatra, Malay Peninsula . .

27. F. araneosa

b. Leafy twigs brown tomentose to subvillous; figs axillary, solitary (or in pairs) 60

60a. Epidermis of the petiole flaking off; lower surface of the lamina hairy on the main veins; fig receptacle globose to ovoid. - New Guinea . . . . 40. F. ovatacuta

b. Epidermis of the petiole persistent; lower surface of the lamina hairy also on the smaller veins; fig receptacle ellipsoid. - New Guinea . . . 30. F. colobocarpa

61a. Lamina sparsely puberulous to subtomentose beneath; basal bracts 1-2 mm long. - New Guinea ...................... 57.F. pleiadenia

b. Lamina densely floccose-tomentose beneath; basal bracts c. $3 \mathrm{~mm}$ long. - New Guinea ...................... 52. F. cinnamomea

62a. Lamina \pm scabrous beneath, with very sparse and/or minute (cystolith) hairs.

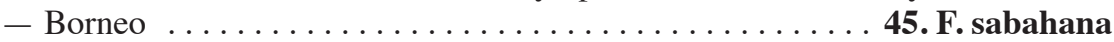

b. Lamina smooth beneath, or if scabridulous, then distinctly hairy . . . . . . 63

63a. Tertiary venation scalariform; lamina usually or often longer than $10 \mathrm{~cm}$, occasionally less than $5 \mathrm{~cm}$ long . . . . . . . . . . . . . . . . . . 64

b. Tertiary venation reticulate or to subscalariform (with few, \pm irregular, transverse (parallel) tertiary veins), in particular, in relatively large leaves; lamina always or often less than $10 \mathrm{~cm}$ long, often less than $5 \mathrm{~cm}$ long . . . . . . . . . . 80

64a. Figs on spurs below the leaves (but already developing in the leaf axils), if the figs small, then often clustered, or if large, then often in pairs or solitary . . 665

b. Figs in pairs or solitary in the leaf axils or just below the leaves . . . . . . 71

65a. Basal bracts $2-7 \mathrm{~mm}$ long; fig receptacle usually $1.2-3.5 \mathrm{~cm}$ diam.; figs solitary

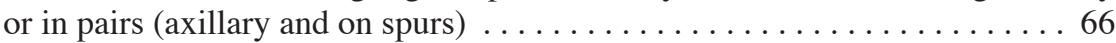

b. Basal bracts $0.5-2 \mathrm{~mm}$ long; figs usually $0.5-1.2 \mathrm{~cm}$ diam. when dry; figs often in clusters of more than 2 (axillary and on spurs) . . . . . . . . . 67

66a. Fig receptacle glabrous; indumentum without irritant hairs. - New Guinea ...

29. F. camptandra

b. Fig receptacle hairy; indumentum partly with irritant hairs. - Moluccas, New

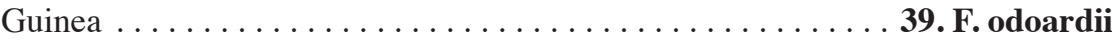

67a. Lateral veins of the lamina slightly prominent, the smaller veins (almost) flat beneath, the areoles smooth; hairs on the lamina appressed . . . . . . . 68

b. Lateral veins and smaller veins of the lamina prominent beneath, the areoles often minutely bullate; hairs on the lamina often \pm patent . . . . . . . . . 69 
68a. Lateral veins $6-10$ pairs; fig receptacle usually $0.5-1 \mathrm{~cm}$ diam. when dry. - Widespread

27. F. sagittata

b. Lateral veins 3-6 pairs; fig receptacle $0.3-0.5 \mathrm{~cm}$ diam. when dry. - Widespread $\ldots \ldots \ldots \ldots \ldots \ldots \ldots \ldots \ldots \ldots$ 44e. F. recurva var. urnigera

69a. Lateral veins $6-10$ pairs. - Widespread . . . . . . . . . 50. F. villosa

b. Lateral veins $4-6(-7)$ pairs . . . . . . . . . . . . . . . 70

70a. Hairs on the midrib of the lamina beneath appressed or patent, rarely tending to

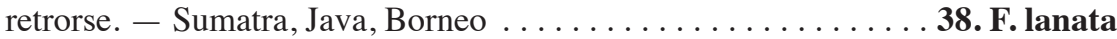

b. Hairs on the midrib of the lamina beneath \pm retrorse. - Philippines . . . . . . .

50. F. villosa

71a. Fig receptacle (usually) $1.2-3.5(-5) \mathrm{cm}$ diam. when dry $\ldots \ldots \ldots \ldots \ldots 72$

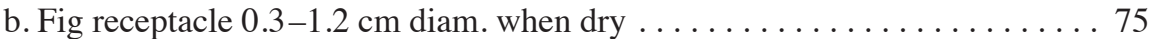

72a. Leafy twigs and lower surface of the lamina very sparsely and inconspicuously hairy. - New Guinea ...................... 37. F. jacobsii

b. Leafy twigs and/or the lamina beneath \pm densely and conspicuously hairy . . 73

73a. Indumentum (in particular that of the fig receptacle) partly consisting of stiff and irritant hairs, which break off easily. - Moluccas, New Guinea 39. F. odoardii

b. Indumentum without irritant hairs $\ldots \ldots \ldots \ldots \ldots \ldots \ldots \ldots$. . . . . . . . 74

74a. Petiole (1-)2-3.5 cm long; stipules $0.5-0.8 \mathrm{~cm}$ long; receptacle non-stipitate; ostiole surrounded by a tuft of hairs. - New Guinea . . . . . . 34. F. fuscata

b. Petiole (0.5-)1-2 cm long; stipules (0.5-)1-2 cm long; receptacle stipitate; ostiole not surrounded by a tuft of hairs. - New Guinea ... . . . 28. F. baeuerlenii

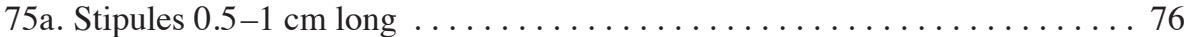

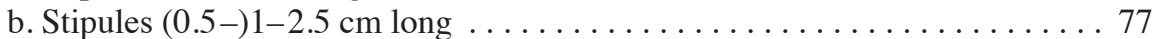

76a. Figs sessile, the receptacle non-stipitate; basal bracts $1.5-2 \mathrm{~mm}$ long. - New

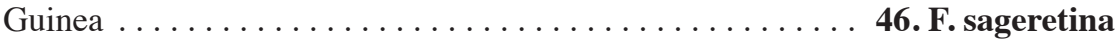

b. Figs (shortly) pedunculate, the receptacle stipitate; basal bracts 3-4 mm long.

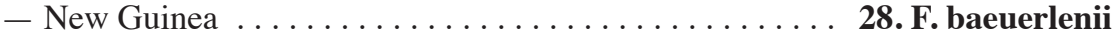

$77 \mathrm{a}$. Indumentum of the fig receptacle short-velutinous (dense), the apex of the receptacle \pm protracted. - New Guinea ............. 28. F. baeuerlenii

b. Indumentum of the fig receptacle hirtellous, strigillose, or absent, the apex of the receptacle convex, flat, or slightly umbonate . . . . . . . . . . 78

78a. Lamina \pm bullate above; indumentum partly consisting of irritant hairs which break off easily; basal bracts 3-7 mm long and free. - New Guinea . . . . . . . .

36. F. insculpta

b. Lamina flat above; indumentum without irritant hairs; basal bracts $2-2.5 \mathrm{~mm}$ long and free or $4-6 \mathrm{~mm}$ long and connate $\ldots \ldots \ldots \ldots \ldots \ldots$

79a. Basal lateral veins up to c. $1 / 3-1 / 2$ the length of the lamina; basal bracts $2-2.5$ $\mathrm{mm}$ long and free; receptacle sparsely puberulous and brown pulverulent. - New

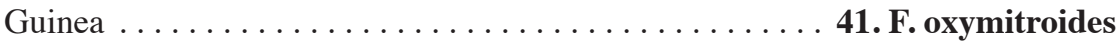

b. Basal lateral veins up to c. $1 / 5-1 / 3$ the length of the lamina; basal bracts $4-6 \mathrm{~mm}$ long and connate; receptacle brown hirtellous. - Moluccas, New Guinea . . . . .

31. F. devestiens

80a. Figs in clusters of more than 2 in the leaf axils and on short spurs below the leaves; fig receptacle $0.3-0.6 \mathrm{~cm}$ diam. when dry $\ldots \ldots \ldots \ldots \ldots \ldots \ldots \ldots$

b. Figs in pairs or solitary in the leaf axils or also on spurs on the older wood; fig receptacle $(0.5-) 0.6-1 \mathrm{~cm}$ diam. when dry. - New Guinea . . . . . . . . 83 
81a. Leafy twigs sparsely (and minutely) hairy. - Widespread

44e. F. recurva var. urnigera

b. Leafy twigs densely hairy $\ldots \ldots \ldots \ldots \ldots \ldots \ldots \ldots \ldots \ldots \ldots \ldots \ldots \ldots \ldots \ldots$

82a. Stipules (0.3-)1-2 cm long; petiole brown hirtellous. - Sumatra, Malay Penin-

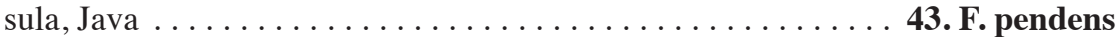

b. Stipules $0.5-0.8 \mathrm{~cm}$ long; petiole densely pale brown to greyish floccose-villous. - Sumatra, Malay Peninsula ... . . . . . . . . . . . 27. F. araneosa

83a. Lamina \pm scabrous above. - New Guinea . . . . . . . 26. F. ampulliformis

b. Lamina smooth above . . . . . . . . . . . . . . . . . 84

84a. Lamina glabrous beneath. - Celebes (?), Moluccas, New Guinea . . . . . . . . . 42. F. pantoniana

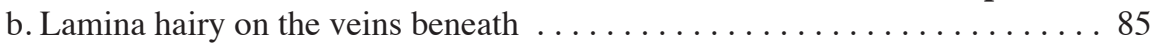

85a. Lamina brown floccose-tomentose beneath; lateral veins (5-)6-9 pairs, the basal pair up to $1 / 5-1 / 3$ the length of the lamina. - New Guinea . 33. F. floccifera

b. Lamina brown (sub) strigillose beneath; lateral veins 4 or 5 , the basal pair up to $1 / 3-1 / 2$ the length of the lamina. - New Guinea . . . . 35. F. hypobrunnea

\section{ACKNOWLEDGEMENTS}

The Flora Malesiana Foundation supports the preparation of the treatment of Moraceae for Flora Malesiana. Dr. J.F. Veldkamp (Leiden) translated the diagnoses into Latin. Hendrieke Berg (Voss, Norway) prepared the drawings.

\section{REFERENCES}

Berg, C.C. 2003. Flora Malesiana precursor for the treatment of Moraceae 1: The main subdivision of Ficus: the subgenera. Blumea 48: 167-178.

Blume, C.K. 1825. Bijdrage tot de flora van Nederlandsch Indië. Batavia.

Corner, E.J.H. 1960. Taxonomic notes on Ficus Linn., Asia and Australasia. V. Subgen. Ficus sect. Rhizocladus, Kalosyce, Sinosycidium, Adenosperma, and Neomorphe. Gard. Bull. Singapore 18: $1-35$.

Corner, E.J.H. 1962. Taxonomic notes on Ficus Linn., Asia and Australasia. Addendum II. Gard. Bull. Singapore 19: 385-401.

Corner, E.J.H. 1965. Check-list of Ficus in Asia and Australasia with keys to identification. Gard. Bull. Singapore 21: 1-186.

Diels, L. 1935. Die Moraceen von Papuasien. In: C. Lauterbach, Beiträge zur Flora von Papuasien, XXI. Bot. Jahrb. Syst. 67: 169-235.

Endlicher, S.L. 1848. Gen. Pl. Suppl. 4, 2. Wien.

Kochummen, K.M. 1998. New species and variations of Moraceae from Malaysia. Gard. Bull. Singapore 50: 197-219.

Miquel, F.A.W. 1847. Prodromus Monographiae Ficuum. London J. Bot. 6: 514-588.

Miquel, F.A.W. 1848. Prodromus Monographiae Ficuum. London J. Bot. 7: 64-78, 198-116, 221-236, 425-442, 451-471, 536-564.

Miquel, F.A.W. 1867. Annotationes de Ficus speciebus. Ann. Mus. Lugd.-Bat. 3: 260-315. Leiden.

Sata, T. 1944. A monographic study of the genus Ficus from the point of view of economic botany. Contr. Hort. Inst. Taihoku Imp. Univ. 32: 1-405, t. 1-54.

Summerhayes, V.S. 1929. Ficus species collected for the Arnold Arboretum in New Guinea by L.J. Brass. J. Arnold Arbor. 10: 142-154.

Winkler, H.J.P. 1913. Beiträge zur Kenntnis der Flora und Pflanzengeograpie von Borneo. III. Bot. Jahrb. Syst. 49: 349-380. 